\title{
A 10 year study at four sites of the middle course of the River Loire I - Patterns of change in hydrological, physical and chemical variables in relation to algal biomass
}

\author{
Dix ans d'étude au droit de quatre sites \\ du cours moyen de la Loire. \\ 1 - Modélisation des modifications des caractéristiques \\ hydrologiques et physico-chimiques \\ en relation avec la biomasse algale
}

\section{Nicole Lair, Denis Sargos}

Universite Blaise Pascal, URA 138, Laboratoire de Biologie des Protistes, Hydrobiologie, 63177 Aubière Cedex, France

\begin{abstract}
Summary. - The hydrobiological, physico-chemical characteristics and algal biomass were studied for ten years at the level of Dampierre-en-Burly, Saint-Laurent des Eaux and Chinon situated in the mean part of the River Loire from spring to Autumn. We proceeded to modelling data of 12 abiotic parameters and 1 biological parameter and then to graphical representation of Principal Component Analysis in order to determine the major characteristics of this part of the River. We examined the differences between the upstream and downstream sites and the average seasonal pattern of the River, and the between-months and between-years variability. The characteristics of the middle Loire are typical of an eutrophic river, nutrients were never depleted in these sites. Flow was the most influential factor on the changes in algal biomass. The inter-month analysis illustrated the displacements of the time course of the seasons from upstream to downstream. An increase of the algal biomass was observed from Dampierre-en-Burly to Saint-Laurent des Eaux in relation with the decrease in nutrients and silicate, while the algal biomass was globally lower at the downstream site of Chinon. The inter-month variability seemed to be higher than the inter-annual changes. These results will conduce to observe with more attention the seasonal succession of algae.
\end{abstract}

Key words; - Running waters - Data modelling - Hydrology - Physico-chemical characteristics - Seasonal pattern - Algal biomass. 
Résumé. - Les caractéristiques hydrologiques et physico-chimiques de la Loire moyenne ont été suivies du printemps à l'automne au niveau de Dampierre-en-Burly, Saint-Laurent des Eaux et Chinon sur une période de dix années. Afin de déterminer, dans cette partie de fleuve, les caractéristiques présidant au développement de la biomasse algale d'amont en aval, 1 variable biotique et 12 variables abiotiques ont été modélisées, des Analyses en Composantes principales en ont permis la représentation graphique.

La Loire moyenne est un fleuve typiquement eutrophe, dans lequel les éléments nutritís ne sont pas limitants. Le débit est le facteur explicatif essentiel des changements de biomasse algale observés et l'analyse inter-mensuelle illustre le décallage saisonnier du développement algal qui se produit d'amont en aval. La biomasse algale augmente de Dampierre-en-Burly à Saint-Laurent des Eaux, parallèlement à la diminution des teneurs en nitrates, phosphates et silice. Cette biomasse est plus faible à Chinon, situé en aval. La variabilité inter-mensuelle est plus importante que la variabilité inter-annuelle. Les changements observés d'amont en aval, nous conduiront à étudier plus en détail la succession saisonnière des communautés algales.

Mots-clés. -Eaux courantes - Modélisation - Hydrologie - Physico-chimie - Variations saisonnières - Biomasse algale.

\section{INTRODUCTION}

The Loire is the main River draining France, with respect to its length. Since 1976 its economic importance has led "Electricité de France" (EDF) to undertake a surveillance programme of impact assessment of the water used for cooling power plants, by comparison of upstream and downstream stations (Lair et al., 1978; Lair, 1980; Lair et al., 1980; Lair \& Sargos, 1981; Khalanski, 1987). The sites studied were Belleville-sur-Loire, Dampierre-en-Burly, Saint-Laurentdes-Eaux and Chinon, situated between 537 and $796 \mathrm{~km}$ from the source. We have collected data since 1976 , our sampling protocol was conducted at different frequencies in relation to the objectives of the surveillance programme.

Our research focused on the hydrological and physico-chemical variables related to changes in the algal biomass over a period of 10 years, in order to determine the major characteristics of this part of the River. First we will examine the River at Dampierre-en-Burly, considering the results obtained at the upstream station only. Second, we will compare our results with the other sites, according to the sets of sampling data available for comparison, with special reference on the action of flow, temperature and nutrients.

\section{DESCRIPTION OF THE SITES AND METHODS}

The River Loire has a drainage area covering $115,000 \mathrm{~km}^{2}$ of the central and west part of France, representing about $1 / 5$ of the country. After $1,012 \mathrm{~km}$ it reaches the Atlantic Ocean with a mean flow of $800 \mathrm{~m}^{3} \cdot \mathrm{s}^{-1}$. 
The Belleville-sur-Loire site was studied from 1976 to 1978, and again in 1986. The Dampierre-en-Burly site, which was canalized in the 19th century, was studied from 1977 onwards. The Saint-Laurent-des Eaux site was canalized during the building of the power plant; it was studied from 1976 onward. Different parameters were regularly analysed at these two sites over ten years. The site of Chinon is situated just after the confluence of Loire and Indre; it was studied from 1976 to 1986 (fig. 1, table I).

The flow was monitored at Gien and Blois. At each power plant one sampling station was situated upstream, and depending on the

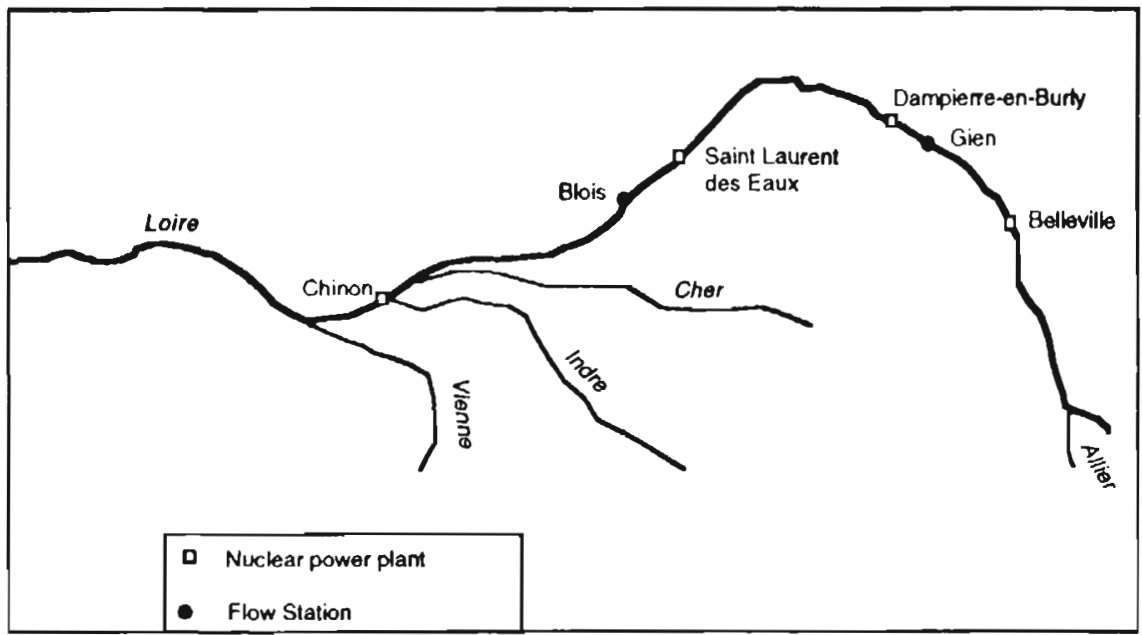

Fig. 1. - Location of nuclear power plants in the course of the River Loire.

Fig. 1. - Localisation des centrales nucléaires.

Table I. - Morphological characteristics of the sites.

Tableau I. - Caractéristiques morphologiques des sites.

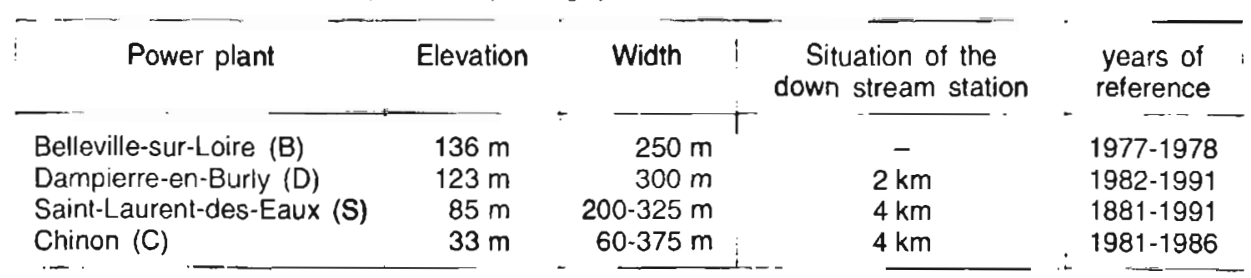


years and characteristics of the sites, one or two stations were studied downstream (Lair et al., 1980). Water samples for physical, chemical and biological analyses were taken. Variables such as conductivity $\left(\mu \mathrm{s} \cdot \mathrm{cm}^{-2}\right)$ linked to mineralisation of water, $t^{\circ} \mathrm{C}$ (thermistor ${ }^{\circ} \mathrm{C}$ ), $\mathrm{pH}\left(\mathrm{pH}\right.$ meter) and $\mathrm{O}_{2}$ (oxymeter $\mathrm{mg} \cdot \mathrm{l}^{-1}$ ) linked to photosynthetic activity were measured in situ. $\mathrm{BOD}_{5} \quad\left(\mathrm{mg} \cdot l^{-1}\right), \quad \mathrm{NH}_{4} \quad\left(\mathrm{mg} \cdot l^{-1}\right), \quad \mathrm{NO}_{3}$ $\left(\mathrm{mg} \cdot \mathrm{l}^{-1}\right), \mathrm{PO}_{4}\left(\mathrm{mg} \cdot \mathrm{l}^{-1}\right), \mathrm{SiO}_{2}\left(\mathrm{mg} \cdot \mathrm{l}^{-1}\right)$, linked to biological activity, oxydability (mg. $\mathrm{I}^{-1}$ ) linked to concentration in organic matter and suspended matter (SM in $\mathrm{mg} \cdot \mathrm{l}^{-1}$ ) were measured according to the norm NFT and reported from the S.R.A.E. of Orléans.

Hydrolicity was expressed as average annual flow divided by average flow of the fifty precedent years. Algal biomass was determined on the basis of cell numbers converted to biovolumes. The data were recorded in the annual reports established for EDF.

Normalised Principal Component Analysis (PCA) was employed to reduce the variables, which consisted of 1 biological and 12 abiotic parameters, into a small number of factors incorporating most of the variability present in the original data. The discrimination between years was judged by examining the projection of plots of the extracted factor on the factorial plane formed with the first two axis of the PCA analysis (Dolédec \& Chessel, 1987). The comparison of the seasonal and annual variability was conducted using the "inter-class" analysis proposed by Dolédec \& Chessel
(1989), the matrix of the 10 data series was ordered by averaging the monthly data and the yearly data (fig. 2).

According to Carrel et al., (1986), we used scores for data modelling and proceeded to the graphic representation of the superposition of normalized values of the $j^{\text {th }}$ variables at the $i^{\text {th }}$ sampling dates $y_{i j}^{\prime}$ in order to obtain the best model defined by the first (and second) axis of PCA, as follows:

model of range $\mathrm{k}$ (rebuilt values): $y_{i j, f}^{\prime}=\Sigma_{f=1, k}\{1 / \overline{\bar{\lambda} f}\} L_{i f} C_{j t}$.

with

$\lambda f=$ eigen value $k$

$\mathrm{L}_{\mathrm{it}}=$ principal coordinates of row $\mathrm{i}$

$\mathrm{C}_{\mathrm{jf}}=$ factorial coordinates of column $\mathrm{j}$

The resulting model is an exploratory tool of data, the properties of the model arising from the data themselves (Chessel \& Dolédec, 1992). This technique was used as a tool to reconstitute each of the discriminated factors, and to verify the significance of axes.

\section{THE CHARACTERISTICS OF THE MIDDLE LOIRE}

The middle Loire has a nivo-pluvial regime and climatic fluctuations, combined with local geomorphology, induce large variations in the flow from year to year. The extreme physical and chemical characteristics of the water, measured at the level of the nuclear power plants between 1977 and 

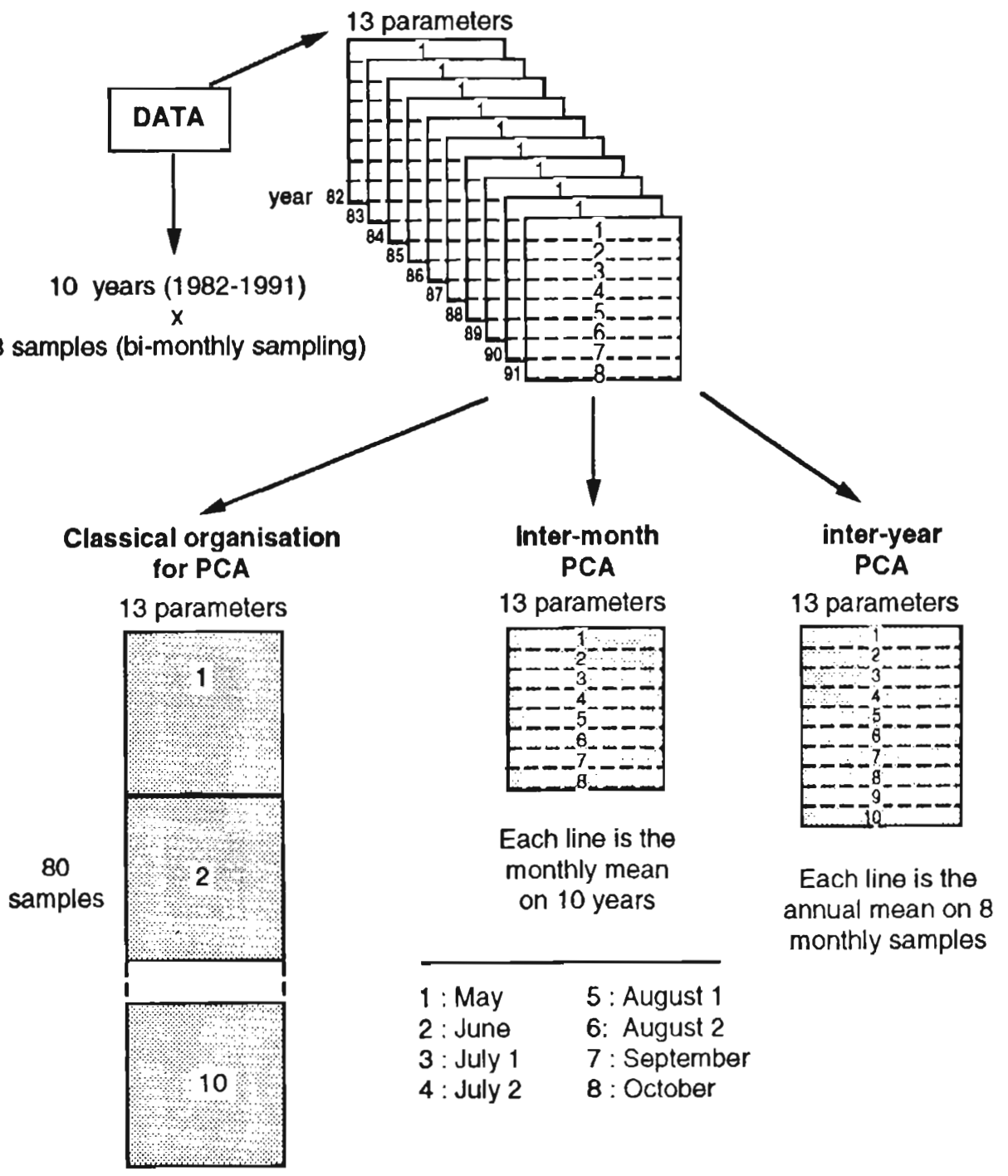

Fig. 2. - Scheme of the PCA and "inter-ciass" analysis of data.

1991, are summarized in table II. Dissolved nutrient concentrations of the water were moderately high and never scarce enough to be the major factors limiting algal development. The values are characteristics of the eutrophic state of the River.

The physical and chemical parameters measured from 1982 to 1991 at Dampierre-en-Burly and Saint-Laurent 
des Eaux and from 1982 to 1986 at Chinon (fig. $3 A \& B$ ) which are globally reproduced from upstream to downstream, in the course of the years, have conducted to describe the average seasonal pattern of River characteristics as follows:

- May = high flow, low algal biomass

- June = depending on the year, the flow decreases progressively from June - July onwards; therefore the decreased flow (associated with an in- crease in temperature) induces the algal growth.

- July = following the algal growth, there is an increase of $\mathrm{pH}$ and, as a consequence, a decrease of $\mathrm{SiO}_{2}$ and $\mathrm{NO}_{3}$ except at Chinon, where the algal biomass was lower as observed by Lair \& Sargos (1981) in 1977-1978.

- August $=\mathrm{pH}$ and $\mathrm{O}_{2}$ are influenced by the maximum algal biomass, which is linked with high $B O D$ values.
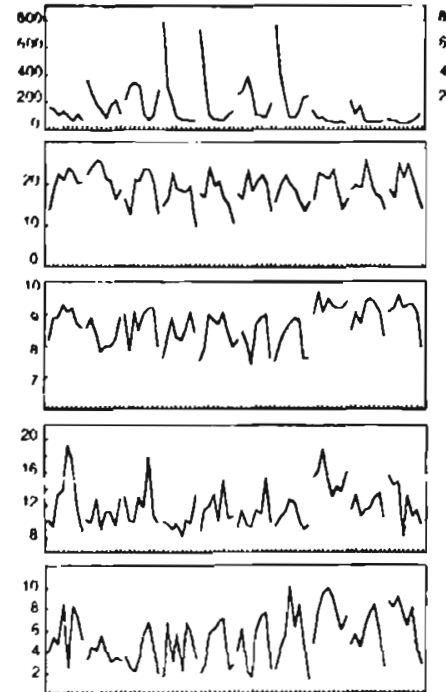

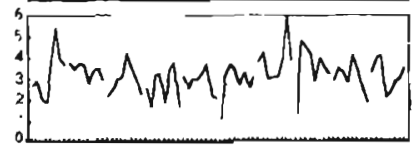

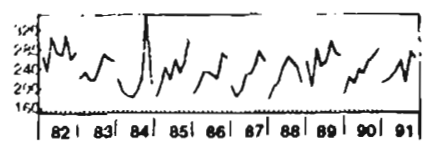

DAMPIERRE

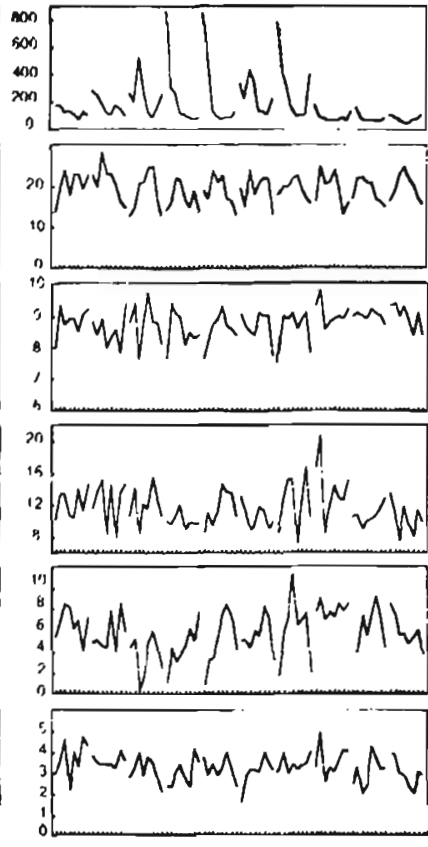

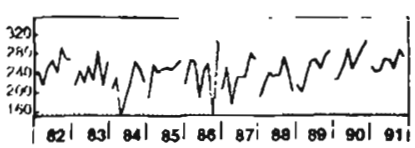

St LAURENT des EAUX

Fig. $3 A$
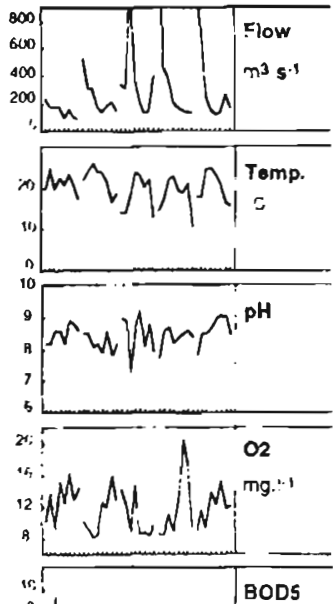

:in $M N N^{n}$

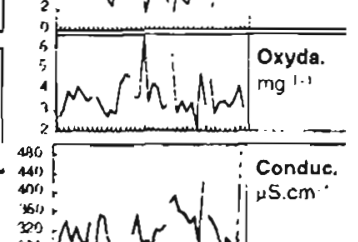

:Noh ho pos

(x),

$|82|_{83 \mid} 84 \mid$ 85i

CHINON

\section{A}


- September $=$ the algal density decreases.

- October = simultaneously with autumn rising flow, the algal populations decline and as a consequence $\mathrm{PO}_{4}$ increases.

On the basis of this scheme, we will examine the differences between the upstream and downstream sites.

\section{DAMPIERRE-EN-BURLY}

We have selected eight series of samples collected upstream from 1982 to 1991 from spring to autumn and studied their seasonal characteristics. The flow rate in the River may attain maxima of $3,000 \mathrm{~m}^{3} \cdot \mathrm{s}^{-1}$ during spring, while it usually decreased during summer, reaching values less than $50 \mathrm{~m}^{3} \cdot \mathrm{s}^{-1}$. Since 1988 it was controlled at $60 \mathrm{~m}^{3} \cdot \mathrm{s}^{-1}$ minimum and maintained by the man made lakes of Villerest and Naussac.

\section{Relationships between abiotic and biotic variables}

We introduced algal biomass (cell numbers converted to biovolumes) as
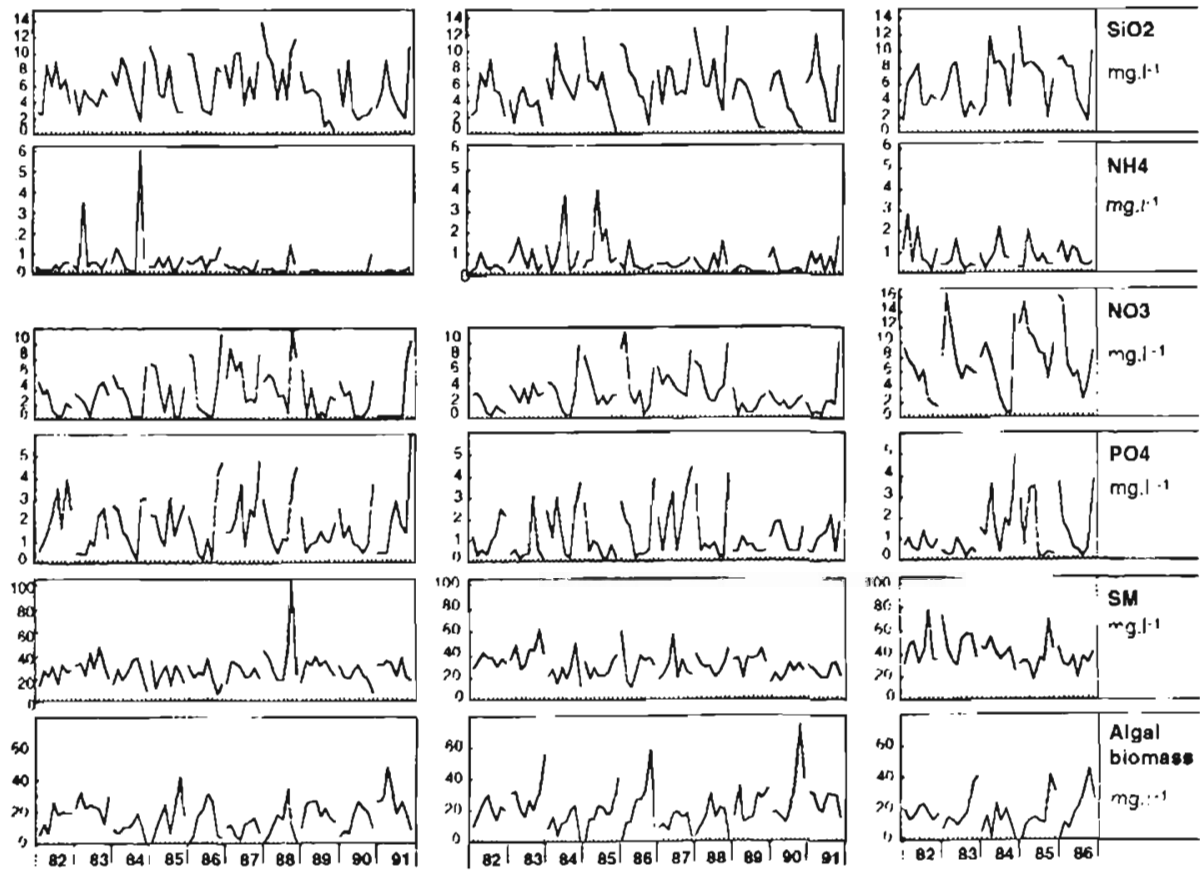

DAMPIERRE

St LAURENT des EAUX

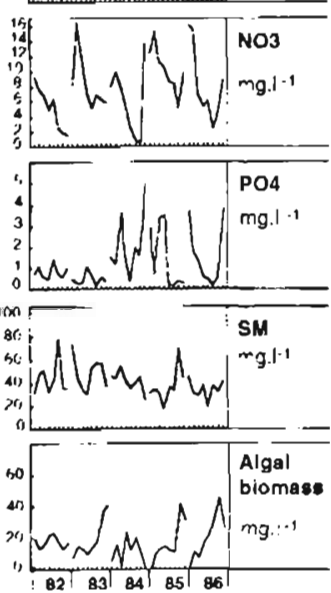

CHINON

B

Fig. 3B

Fig. 3. - Variations of the parameters mesured at Dampierre-en-Burly, Saint-Laurent des Eaux from 1982 to 1991 and Chinon from 1982 to 1986.

Fig. 3. - Variations des paramètres mesurés de 1982 à 1991 au niveau de Dampierre-en-Burly, et Saint-Laurent des Eaux et de 1982 à 1986 à Chinon. 
Table II. - General data collected from 1977 to 1991, the sampling protocol depending on the surveillance programmes conducted at the different places. $(B)=$ Belleville-surLoire, $(\mathrm{D})=$ Dampierre-en-Burly, $(\mathrm{S})=$ Saint-Laurent-des-Eaux, $(\mathrm{C})=$ Chinon, $(\mathrm{K})=$ Khalanski, 1976).

Tableau II. - Synthèse des données recueillies de 1977 à 1991 aux différents sites, et selon des fréquences dépendant des programmes de surveillance.

\begin{tabular}{|c|c|c|c|c|}
\hline variables & $\begin{array}{c}\text { minimum } \\
\text { maximum* } \\
\text { mean } \\
(B) \\
1977-78\left(86^{*}\right)\end{array}$ & $\begin{array}{c}\text { minimum } \\
\text { maximum } \\
\text { mean } \\
\text { (D) } \\
1982-91\end{array}$ & $\begin{array}{c}\text { minimum } \\
\text { maximum } \\
\text { mean } \\
(S) \\
1981-91\end{array}$ & $\begin{array}{c}\text { minimum } \\
\text { maximum } \\
\text { mean } \\
(C) \\
1981-86\end{array}$ \\
\hline Conductivity $\left(\mu \mathrm{S} \mathrm{cm} \mathrm{cm}^{-1}\right)$ & $\begin{array}{c}(231) \\
(268) \\
263\end{array}$ & $\begin{array}{l}180 \\
348 \\
240\end{array}$ & $\begin{array}{l}133 \\
306 \\
240\end{array}$ & $\begin{array}{l}179 \\
488 \\
337\end{array}$ \\
\hline température $\left({ }^{\circ} \mathrm{C}\right)$ & $\begin{array}{c}(11.3) \\
(22.9) \\
17.4\end{array}$ & $\begin{array}{r}9.9 \\
26.0 \\
19.2\end{array}$ & $\begin{array}{l}12.0 \\
28.3 \\
19.3\end{array}$ & $\begin{array}{l}10.8 \\
26.2 \\
20.2\end{array}$ \\
\hline $\mathrm{pH}$ & $\begin{array}{c}(8.2) \\
(9.6) \\
7.8\end{array}$ & $\begin{array}{l}7.4 \\
9.7 \\
8.7\end{array}$ & $\begin{array}{l}7.5 \\
9.8 \\
8.8\end{array}$ & $\begin{array}{l}7.3 \\
9.2 \\
8.4\end{array}$ \\
\hline oxygen (mg.l') & $\begin{array}{c}(10.2) \\
(18.2) \\
3.2\end{array}$ & $\begin{array}{r}8.3 \\
19.3 \\
11.9\end{array}$ & $\begin{array}{r}7.2 \\
20.8 \\
11.9\end{array}$ & $\begin{array}{r}8.2 \\
20.5 \\
11.7\end{array}$ \\
\hline BOD5 (mg. ' ') & & $\begin{array}{r}0.5 \\
10.1 \\
5.3\end{array}$ & $\begin{array}{r}0.5 \\
11.3 \\
5.9\end{array}$ & $\begin{array}{l}1.6 \\
9.3 \\
5.0\end{array}$ \\
\hline $\mathrm{NH}_{4}\left(\mathrm{mg} \cdot \Gamma^{1}\right)$ & $\begin{array}{c}(<0.010) \\
(0.033) \\
0.011\end{array}$ & $\begin{array}{l}0.01 \\
0.60 \\
0.05\end{array}$ & $\begin{array}{c}0.01 \\
0.41 \\
0.065\end{array}$ & $\begin{array}{l}0.02 \\
0.29 \\
0.08\end{array}$ \\
\hline $\mathrm{NO}_{3}\left(\mathrm{mg} \cdot \Gamma^{-1}\right)$ & $\begin{array}{c}(<0.5) \\
(6.4) \\
7.0\end{array}$ & $\begin{array}{r}0.5 \\
12.0 \\
3.6\end{array}$ & $\begin{array}{r}0.5 \\
11.3 \\
3.6\end{array}$ & $\begin{array}{r}0.5 \\
17.8 \\
7.7\end{array}$ \\
\hline $\mathrm{PO}_{4}\left(\mathrm{mg} \cdot \Gamma^{-1}\right)$ & $\begin{array}{c}(0.04) \\
(0.55) \\
0.73\end{array}$ & $\begin{array}{l}0.02 \\
0.48 \\
0.18\end{array}$ & $\begin{array}{l}0.02 \\
0.62 \\
0.13\end{array}$ & $\begin{array}{l}0.02 \\
0.51 \\
0.13\end{array}$ \\
\hline $\mathrm{SiO}_{2}\left(\mathrm{mg} \cdot \Gamma^{-1}\right)$ & $\begin{array}{c}\overline{-} \\
\overline{12.9}\end{array}$ & $\begin{array}{r}0.5 \\
13.8 \\
5.9\end{array}$ & $\begin{array}{r}0.5 \\
13.2 \\
5.6\end{array}$ & $\begin{array}{r}1.6 \\
13.0 \\
6.2\end{array}$ \\
\hline $\begin{array}{l}\text { Suspended matter (SM) } \\
\left(\mathrm{mg} \cdot I^{-1}\right)\end{array}$ & $\begin{array}{c}(11.6) \\
(40.5) \\
16.0\end{array}$ & $\begin{array}{r}6.4 \\
104.0 \\
27.7\end{array}$ & $\begin{array}{l}11.2 \\
62.0 \\
33.0\end{array}$ & $\begin{array}{l}18.0 \\
78.8 \\
40.7\end{array}$ \\
\hline Chlorphyll a $\left(\mathrm{mg}^{\left.-\mathrm{m}^{-3}\right)}\right.$ & - & (85.8) & $\begin{array}{c}(67.8) \\
210(\mathrm{~K})\end{array}$ & $(80.6)$ \\
\hline
\end{tabular}



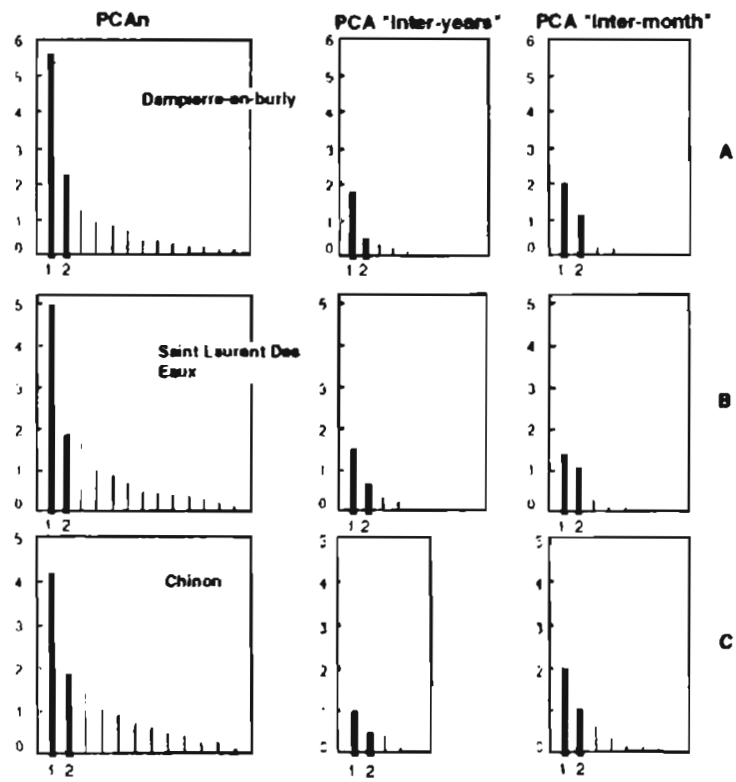

Fig. 4. - Eigen values ( $y$ axis) of factors ( $x$ axis) discriminated by the PCA analysis. PCA = Global analysis. $\mathrm{A}=$ Dampierre-en-Burly, $\mathrm{B}=$ Saint-Laurent des Eaux, $\mathrm{C}=$ Chinon.

Fig. 4. - Valeurs propres (axe des y) des facteurs (axes des $x$ ) de l'analyse globale (PCA) et des analyses inter-années et inter-mois. En gras, figurent les 2 facteurs discriminés par l'analyse.

biological parameter in order to establish what was the importance of biological activity in the variations of the water composition.

The correlations extracted from the matrix corresponding to 80 observations (10 years and 8 sampling series) indicated significative negative correlations between flow and $\mathrm{pH}$, conductivity, $\mathrm{O}_{2}, \mathrm{BOD}$ and algal biomass; positive correlations occured between flow and silicate, nitrates (and phosphates, which were not correlated at 0,01 level). An inverse correlation occured between algal biomass and $\mathrm{PO}_{4}, \mathrm{NO}_{3}$ and silicate. $\mathrm{NH}_{4}$ was independant (table III).
Nine significant factors were extracted on the first axis from the thirteen remaining variables and accounted for $43 \%$ of the variance present in the original transformed data (fig. 4, PCA "A"). The relative contributions are $62 \%, 74 \%, 75 \%$, $46 \%, 73 \%, 42 \%, 75 \%$ respectively for Flow, pH, BOD, $\mathrm{SiO}_{2}, \mathrm{NO}_{3}, \mathrm{PO}_{4}$ and algal biomass. The first axis was chiefly determined by the "growing factors" which correlated with algal biomass (fig. 5A).

Three significant factors were extracted on the second axis which accounted for $17 \%$ of the variance. This axis was determined by oxydability, 
Table III. - Correlation matrix corresponding to 10 (Dampierre-en-Burly, Saint-Laurentdes-Eaux) and 5 (Chinon) years observations and 8 sampling series (each year).

Tableau III. - Matrices de corrélations correspondant aux données recueillies pendant 10 ans aux sites de Dampierre-en-Burly et Saint-Laurent-des-Eaux et recueillies pendant 5 ans au site de Chinon. Elles correspondent à 8 séries de données par an.

$\begin{array}{cc}78 \mathrm{dd} l & \text { Dampierre-en-Burly } \\ \mathrm{r} 0.05=0.22 & (1982-1991)\end{array}$

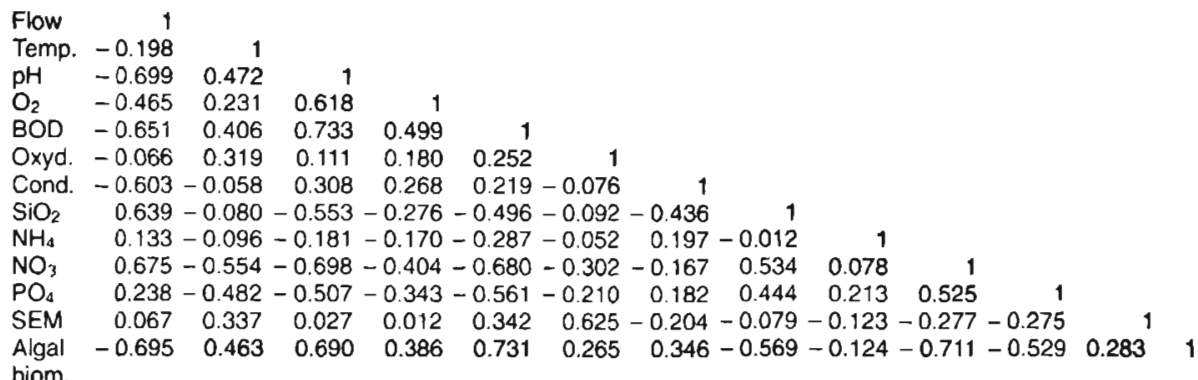

Flow Temp. $\mathrm{pH} \quad \mathrm{O}$ B $\mathrm{BOD}$ Oxyd. Cond. $\mathrm{SiO}_{2} \mathrm{NH}_{4} \mathrm{NO}_{3} \mathrm{PO}_{4} \mathrm{SEM}$ Alg.

$\begin{array}{cc}78 d d l & \text { St-Laurent-des-Eaux } \\ \text { r } 0.05=0.22 & (1982-1991)\end{array}$

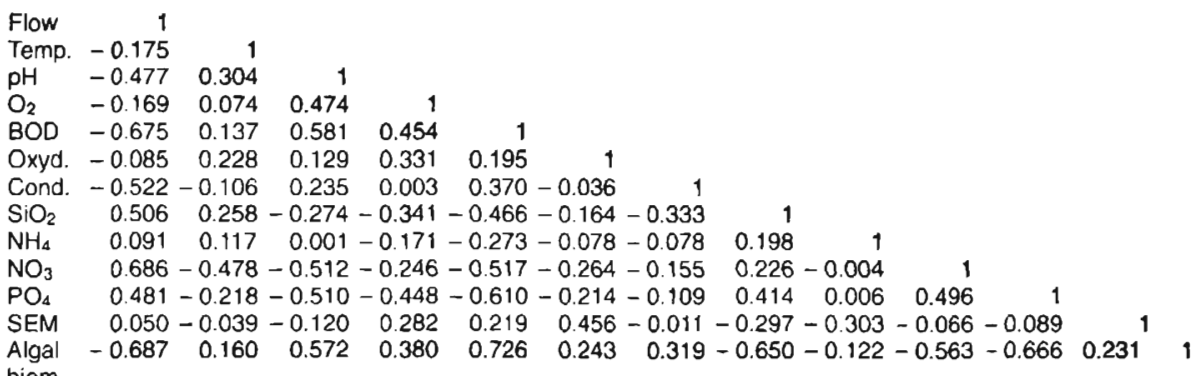

Flow Temp. pH $\mathrm{O}_{2}$ BOD Oxyd. Cond. $\mathrm{SIO}_{2} \quad \mathrm{NH}_{4} \mathrm{NO}_{3} \mathrm{PO}_{4} \mathrm{SEM}$ Alg. 


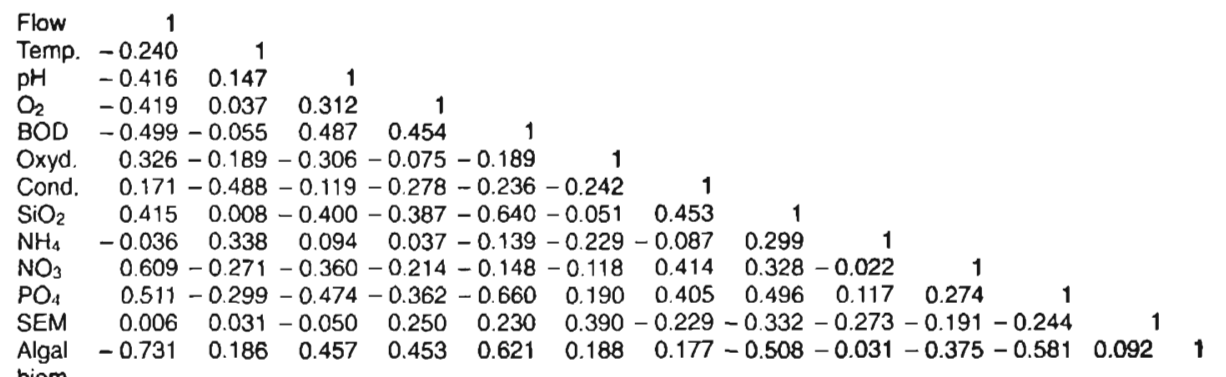

biom.

Flow Temp. $\mathrm{pH} \quad \mathrm{O}_{2}$ BOD Oxyd. Cond. $\mathrm{SIO}_{2} \mathrm{NH}_{4} \quad \mathrm{NO}_{3} \mathrm{PO}_{4} \mathrm{SEM} \begin{gathered}\text { Alg. } \\ \text { bio. }\end{gathered}$

suspended matter and conductivity (the relative contributions are respectively $34 \%, 53 \%$ and $51 \%$ ); flow and temperature were also designated on this axis by significant correlations which replicate the seasonal variations in flow. Only $\mathrm{NH}_{4}$ was not extracted on these two axes, it was independant on the growing and flow factors.

We have reconstituted each of the discriminated variables in order to verify the significance of axes in the modelling technique. Except during the first two years, the values which are rebuilt by the first component (the "growing factors") are fitted to $\mathrm{pH}$, $\mathrm{BOD}, \mathrm{SiO}_{2}, \mathrm{NO}_{3}, \mathrm{PO}_{4}$ and algal biomass values (fig. 6), showing that globally the algal growth depends on these parameters.

Modelling data rebuilt by axis 1 and 2 together accounted for $60 \%$ of the variance, the flow variations are well integrated by this rank 2 model (fig. 6). Oxydability, conductivity and SM are well linked to the second axis (temperature remains relatively independant from both axis). This model reproduced the high spring flow of 1985-1986-1988, the seasonal alternation of high and low flow characteristics of the years 1984 to 1989 , the absence of flooding in 1990 and 1991 and also the perturbations in flow which occured in 1982-1983. This analysis illustrates the importance of this parameter in regard of the River dynamics.

\section{Annual typology}

Based on the mean of the data obtained each month for 10 years, a PCA was applied to reproduce the seasonal dynamics of the River. The eight series of data obtained from May to October ("between-months" analysis) are chronologically ordered in the plane of the first two components which accounted for $72 \%$ of the var- 

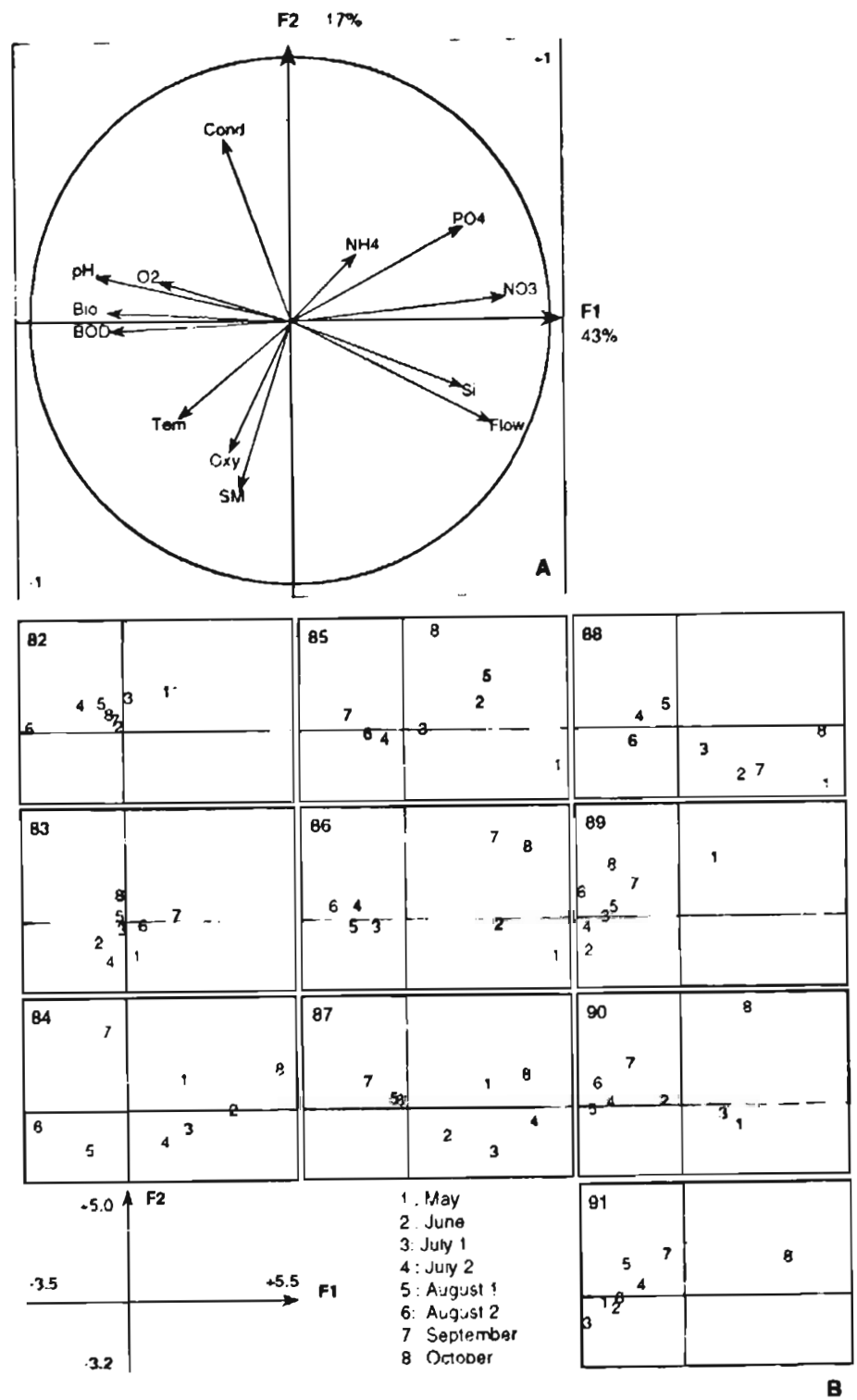

Fig. 5. - Dampierre-en-Burly (1982-1991 data). Situation of the measured variables in the plane of axis $\mid$ and $\|$ resulting from PCA. Bio = algal biomass, $8 O D=$ biological oxygen demand, Cond $=$ Conductivity, $\mathrm{Oxy}=$ oxydability, $\mathrm{Si}=$ silicate, $\mathrm{SM}=$ suspended matter, Tem $=$ temperature. $\mathrm{A}=$ cor relation circle, $\mathrm{B}=$ ordination of dates for the different years.

Fig. 5. - Site de Dampierre-en-Burly (donnèes recueillies de 1982 à 1991). Représentation graphique des variables mesurées sur le plan formé par les axes I et II de l'ACP. Bio = biomasse algale, $\mathrm{BOD}=$ demande biologique en oxygene, $\mathrm{Cond}=$ Conductivité, $\mathrm{Oxy}=$ oxydabilité, $\mathrm{Si}=$ silicates, $\mathrm{SM}$ $=$ matières en suspension, Tem $=$ température. $A=$ cercle des corrélations, $\mathrm{B}=$ Représentation des données correspondant aux différentes années. 

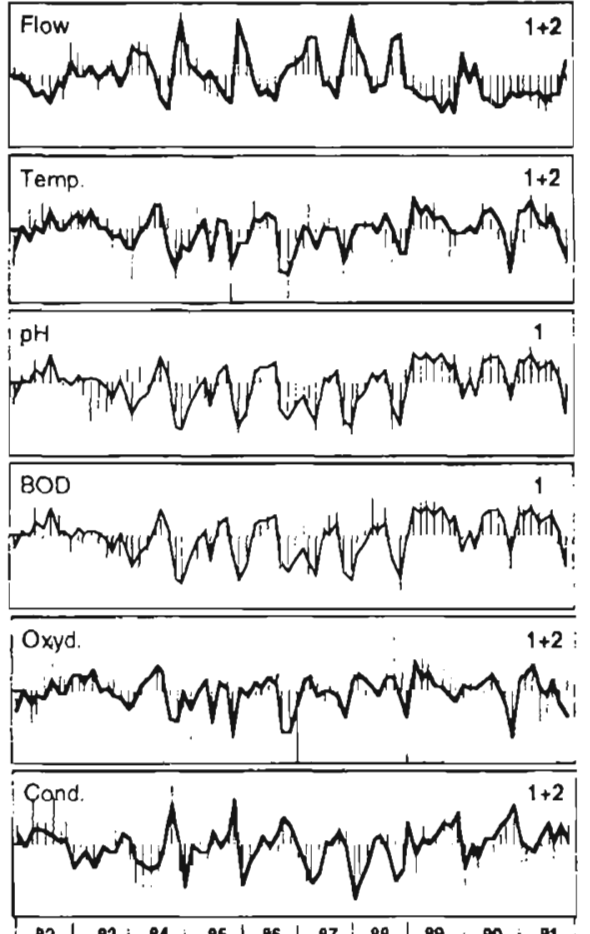

abscissa : [1.80] (sampling dates) ordinate : $[-3+3]$

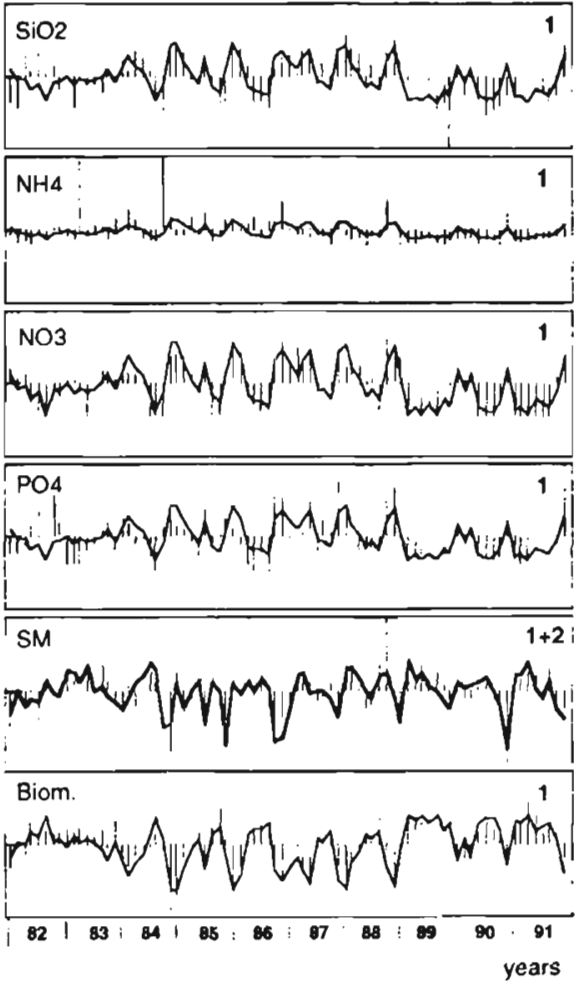

Fig. 6. - Dampierre-en-8urly (1982-1991 data). Modelling data after PCA. Chronologically normalized sampled data (bars) and the best model defined by the first axis of PCA (thick lines) and by the first + second axis of PCA (bold lines).

Fig. 6. - Site de Dampierre-en-Burly (données recueillies de 1982 à 1991). Modélisation des données obtenues par l'ACP. Les barres correspondent aux données normalisées en ordre chronologique et les courbes correspondent au meilleur modèle obtenu sur l'axe 1 (ligne fine) ou sur les axes $1+2$ (ligne épaisse).

lance (fig. 7A). Summer data ( 3 to 7 ) are in opposition to spring $(1-2)$ and autumn data (8) with September in transition (fig. 7B).

The discrimination between years was judged by examining the projection of plots of the extracted factors on the factorial plane formed with the first two axis of the inter-annual analysis (fig. 7C). On the first axis, the years 1982, 1989, 1990, 1991 (low hydrolicity) are in opposition with the years 1983, 1984-1985-1986 (strongly linked) and with the years 1987 . 1988 (high hydrolicity) in relation with the algal growth (fig. 7D). Oxy- 


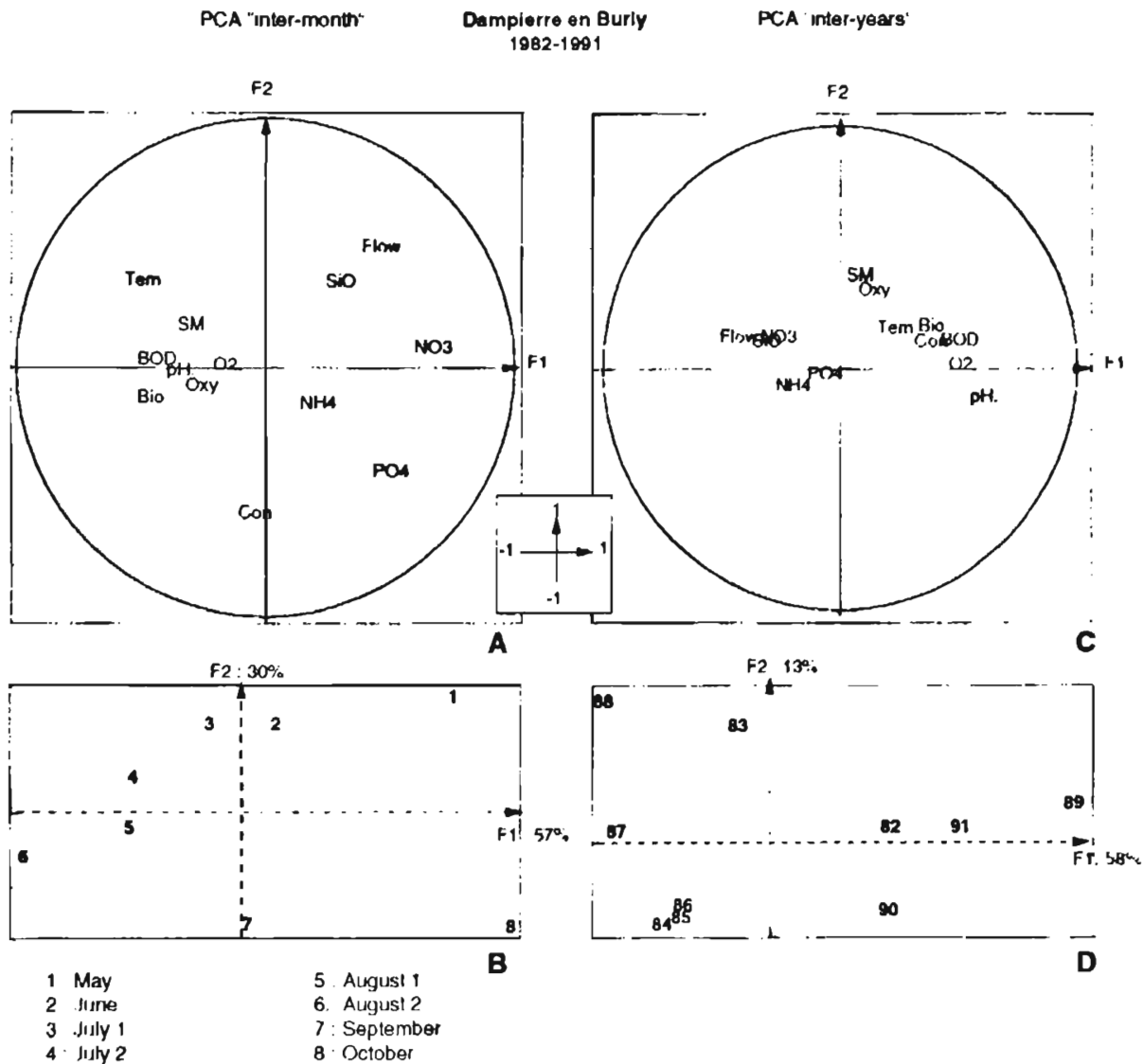

Fig. 7. - Dampierre-en-Burly (1982-1991 data). Situation of the measured variables in the plane of axis I and II resulting from belween-months and between-years analysis, (legends are as in fig. 5).

Fig. 7. - Site de Dampierre-en-Burly (données recueillies de 1982 à 1991). Analyse inter-mensuelle et interannuelle. Représentation graphique des variables mesurées sur le plan formé par les axes I et II de l'ACP. (voir légende détaillée fig. 5).

dability and SM are linked to the second factor which permitted separation of the years 1983 and 1988 from the others.

The following results were examined in relation to the hydrological characteristics obtained from year to year.
The situation of the different sampling sets illustrated the differences between years (fig. 5B). Flushing accounted for nearly all the variance (fig. 6) and permitted integration of the annual variability into 4 types, with the following characteristics: 
- type 1 (1982-89-90-91) = Early, long and stable low water (hydrolycity $<1$ ). These years are characterized by a progressive increase in temperature. This was favourable to biological activities and, as a consequence, the development of an important algal biomass occured at the end of summer. The algal biomass was particularly high in 1990, a year marked by a severe low water, and this tendency was maintained despite small spring floods (cf. plot 3 , spring 1990). The sudden cessation of algal growth in october was illustrated by the interruption of consumption of the nutrients $\mathrm{PO}_{4}$ and $\mathrm{NO}_{3}$ (cf. plot 8) whose quantity increased again.

- type $2(1983)=$ Short summer flood (hydrolicity $\geq 1$ ) and absence of seasonality.

- type $3 \quad(1984-85-86)=$ High spring flow and low water in summer (Hydrolicity = 1 except in June-July). These years may be considered as reference years with regard to the average data. The spatial distribution of scatterplots represented the progressive increase of the algal biomass until the late summer. The spring flood of 1984 was followed by a short low water period. In August 1985 the decrease of algal biomass, illustrated by the displacement of plot 5 , was independant of the characteristic variables. Around the general pattern, 1986 was marked by a clear difference between seasons.

- type $4 \quad(1987-88)=$ Similar to the preceding type (hydrolycity $=1$ or $>1$ in spring or summer), but because of different flooding pattern (spring or summer flood), the monthly variability is different. In comparison with the reference years, the algal biomass is lower, due to dilution. Each flood was associated with a perturbation of algal growth (cf. plot 4, 1987 and plot 7, 1988).

This scheme illustrates the complexity of the dynamics of the River in the region of Dampierre-en-Burly, whose heterogeneity was clearly linked with variations of flow, while the seasonal variations in temperature are not a controlling variable. On the basis of the values of factor 1 (Thioulouse \& Chessel, 1987), the examination of the eigen values (fig. $4 \mathrm{~A}$ ) showed the between-years variability was lower when compared with the between months variability. This indicated that the seasonal effect was greater than the annual effect in this part of the River; it was well marked at the examination of factor 2 .

\section{SAINT-LAURENT-DES-EAUX}

The flow rate in the River may attain maxima of $864 \mathrm{~m}^{3} \cdot \mathrm{s}^{-1}$ during spring, while it usually decreases during summer, reaching values under $47 \mathrm{~m}^{3} \cdot \mathrm{s}^{-1}$. In 1991, the man-made lakes of Villerest and Naussac did not support the flow at $60 \mathrm{~m}^{3} \cdot \mathrm{s}^{-1}$.

\section{Relationships between abiotic and biotic variables}

The correlations extracted from the matrix corresponding to 80 observations (10 years and 8 sampling series) indicated significative negative corre- 
lations between flow, and $\mathrm{pH}, \mathrm{BOD}$, conductivity and algal biomass. Positive correlations occured between flow and silicate, nitrates and phosphates. An inverse correlation occured between algal biomass, nutrients and silicate, $\mathrm{NH}_{4}$ was independant (table III).

As for Dampierre-en-Burly, we have selected data obtained from 1982 to 1991 and performed PCA. The first factorial axis $(32 \%$ of the variance) was chiefly determined by the "growing factors": algal biomass, BOD and the corresponding physico-chemical parameters $\left(\mathrm{pH}, \mathrm{O}_{2}, \mathrm{NO}_{3}, \mathrm{PO}_{4}\right.$ and $\mathrm{SiO}_{2}$ ) and by the flow, with the relative contributions as follows: $78 \%, 73 \%$, $50 \%, 31 \%, 52 \%, 57 \%$ and $40 \%$. Temperature, $\mathrm{NH}_{4}$ and $\mathrm{SM}$ were designated on the second axis which encountered $17 \%$ of the variance (fig. 8A). Their relative contributions are respectively $28 \%, 31 \%$ and $53 \%$.

\section{Annual typology}

We then proceeded to the analysis of the annual typology. The "betweenmonths" analysis, gives a picture of the seasonal dynamics of the River. On the first axis, summer data (4 to 7) are opposed to spring data (1-3) and autumn data (8) with flow, $\mathrm{NO} 3$ and algal biomass as extracted factors. Temperature and silicate are discriminated on the second axis (fig. 9A \& B).

The "between-years" analysis shows that flow and SM are the predominant factors in the River dynam- ics. On the first axis: flow, $\mathrm{NO}_{3}, \mathrm{SiO}_{2}$, $\mathrm{PO}_{4}$ and $\mathrm{NH}_{4}$ (positive values) are in opposition to BOD, algal biomass, conductivity and $\mathrm{pH}$ (negative values), $\mathrm{SM}, \mathrm{O}_{2}$ and oxydability are extracted on the second axis (fig. 9C). On the first axis, the years 1982, 1989, 1990 and 1991 (high hydrolycity) are in opposition with the years 1984, 1985, 1986, 1987 and 1988 (low hydrolicity). The year 1983 is associated with SM on the second axis (fig. 9D).

In comparison with Dampierre-enBurly, this site is situated downstream, the effects of the hydrolicity are attenuated, the lower water period was more severe and the seasonality was less marked. The situation of the different sampling sets illustrated the differences between years (fig. 8B), we can distinguish 3 types only, the years 1987 and 1988 being near to type 3 (reference years) and characterised by a clear difference between seasons.

- type 1 (1982-1989-1990-1991). Low hydrolycity.

- type 2 (1983). Mean hydrolycity.

- type 3 (1984-1985-1986-19871988). High hydrolycity.

We proceeded to the graphic representation of the PCA, to reconstitute each of the discriminated factors among the 13 sets of data. The values which are rebuilt by the first axis are the "growing factors": $\mathrm{pH}, \mathrm{BOD}, \mathrm{NO}_{3}$, $\mathrm{PO}_{4}$ and algal biomass, in relation with flow. The values which are rebuilt by axis 1 and 2 together accounted for $49 \%$ of variance and temperature. $\mathrm{SiO}_{2}, \mathrm{NH}_{4}$ and $\mathrm{SM}$ variations are well 

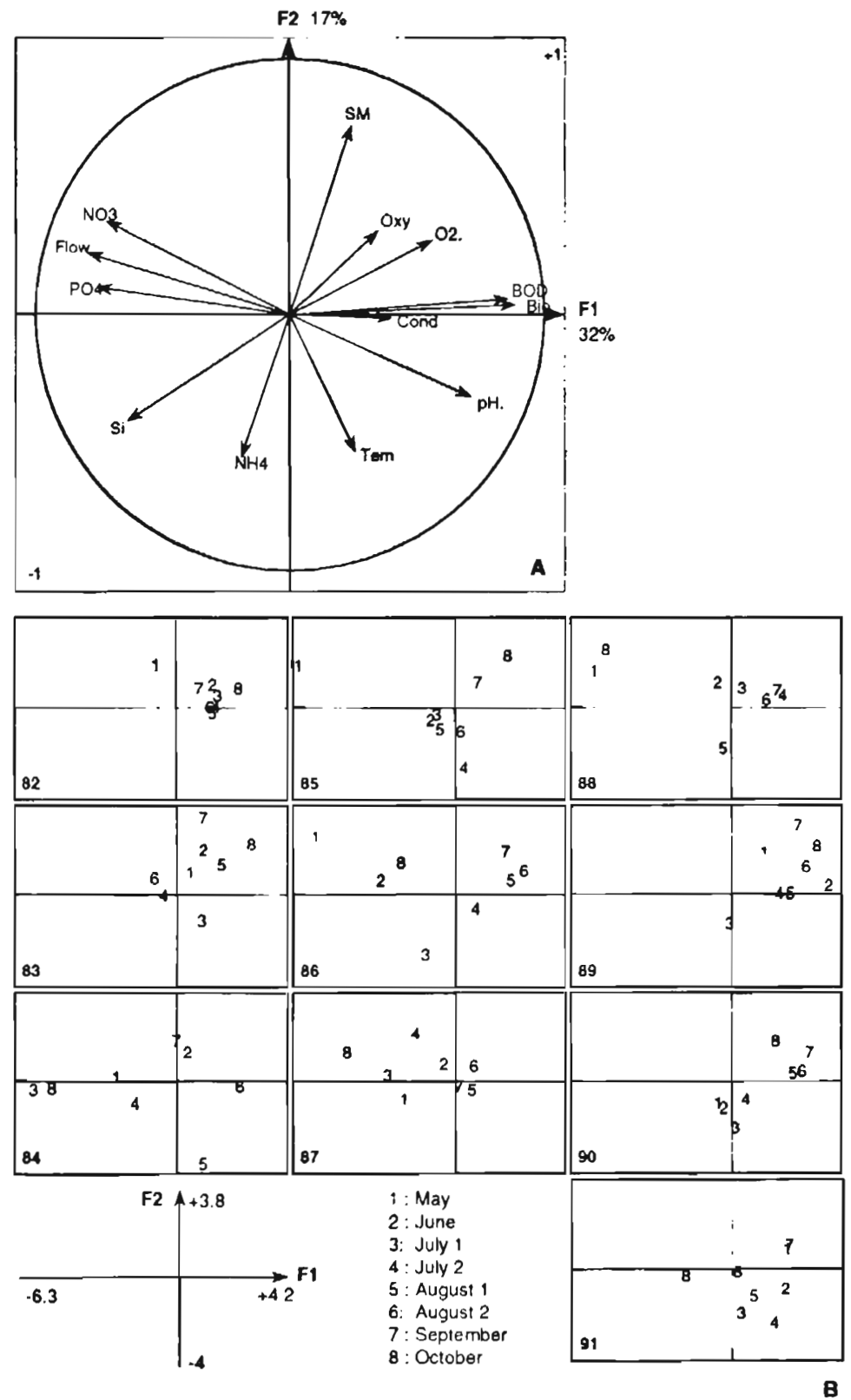

Fig. 8. - Saint-Laurent des Eaux (1982-1991 data). Situation of the measured variables in the plane of axis I and II resulting from PCA (legends are as in fig. 5).

Fig. 8. - Site de Saint-Laurent des Eaux (données de 1982 à 1991). Représentation graphique des variables mesurées sur le plan formé par les axes I et II de l'ACP. (voir légende détaillée fig. 5). 


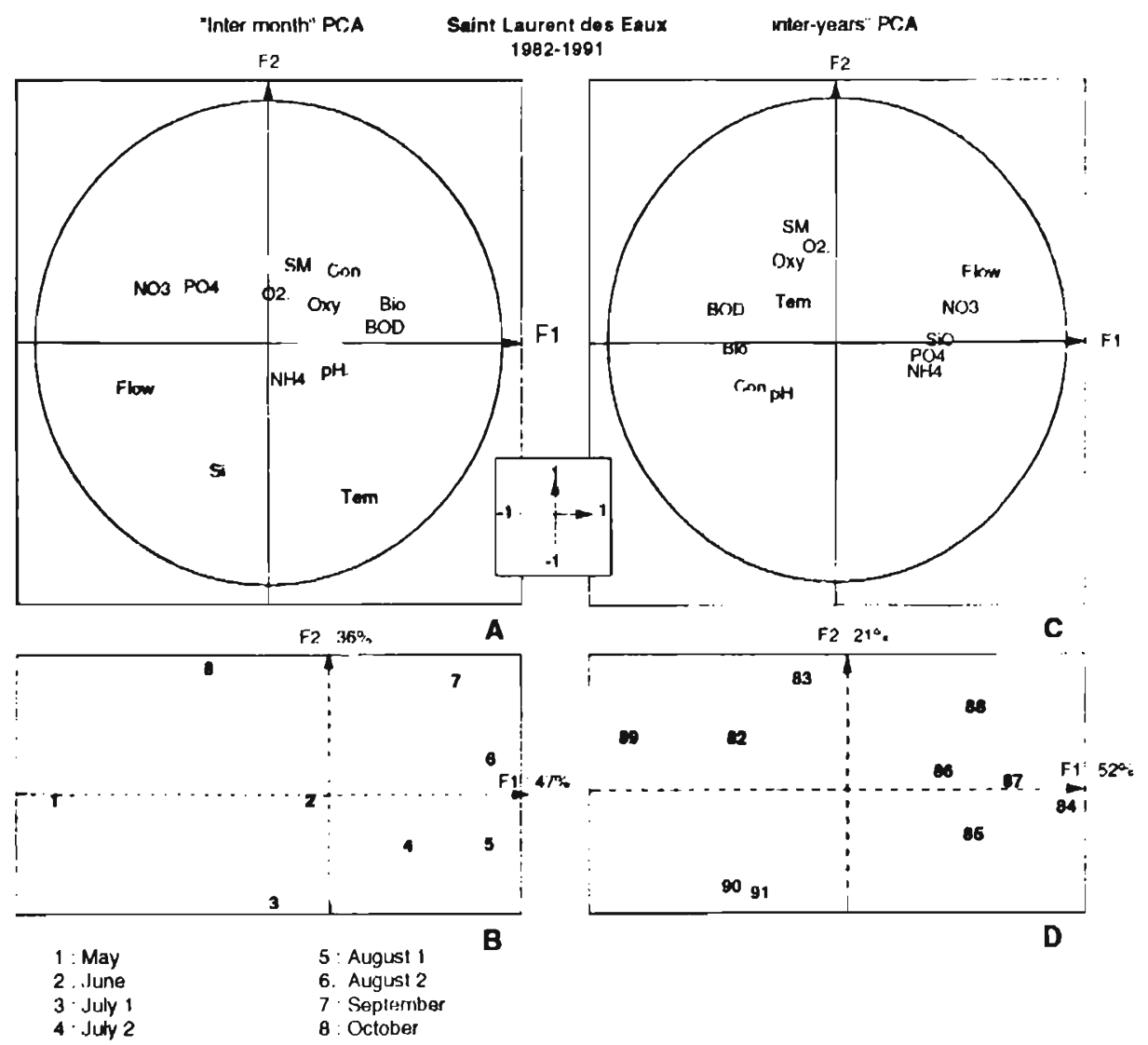

Fig. 9. - Saint-Laurent des Eaux (1982-1991 data). Situation of the measured variables in the plane of axis I and II resulting from between-months and between-years analysis (legends are as in fig. 5).

Fig. 9. - Site de Saint-Laurent des Eaux (données de 1982 à 1991). Analyse intermensuelle et interannuelle. Représentation graphique des variables mesurées sur le plan formé par les axes I et II de l'ACP (voir légende détaillée fig. 5).

integrated by this rank 2 model (fig. 10). The other parameters are not well rebuilt by these axis. These results illustrate the effects of the downstream attenuation of flow and the importance of temperature.

The examination of the eigen values (fig. 4B) showed that the between-years variability was slightly higher that the between-months variability, but the between-months variability was well marked by factor 2 .

\section{THE SITE OF CHINON}

This site was downstream of two tributaries of the Loire and after the large 

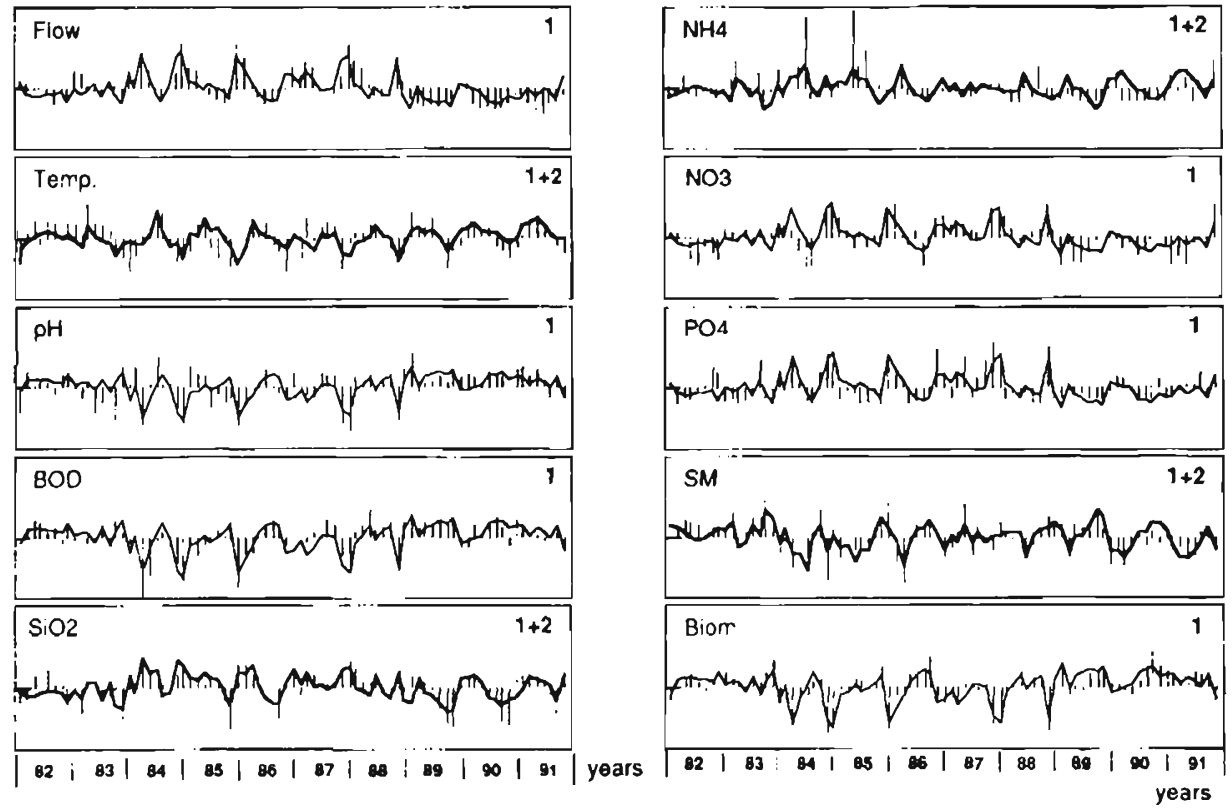

abscissa : $[1.80)$ (samping dates) ordinate : $[-3+3]$

Fig. 10. - Saint-Laurent des Eaux (1982-1991 data). Modelling data after PCA. Chronologically normalized sampled data (bars) and the best model defined by the first axis of PCA (thick lines) and by the firsi + second axis of PCA (bold lines).

Fig. 10. - Site de Saint-Laurent des Eaux (données de 1982 à 1991). Les barres correspondent aux données normalisées en ordre chronologique et les courbes correspondent au meilleur modèle obtenu sur l'axe 1 (ligne fine) ou sur les axes 1+2 (ligne épaisse).

towns of Blois and Tours. The flow rate in the River may attain maxima of $1580 \mathrm{~m}^{3} \cdot \mathrm{s}^{-1}$ during spring, showing the influence of the tributaries. It usually decreases during summer, reaching values below $90 \mathrm{~m}^{3} \cdot \mathrm{s}^{-1}$.

\section{Relationships between abiotic and biotic variables}

The correlations extracted from the matrix corresponding to 40 observations (5 years and 8 sampling series) indicated significative negative correlations between flow and $\mathrm{pH}, \mathrm{O}_{2}, \mathrm{BOD}$ and algal biomass; positive correlations occured between flow and oxydability, silicate, nitrates, phosphates. An inverse correlation occured between algal biomass and nutrients and silicate, $\mathrm{NH}_{4}$ was independant (table III).

We proceeded to the same multivariate analysis as for Dampierre-enBurly and Saint-Laurent des Eaux, on the basis of the data collected from 
1982 to 1986 . From the normalised $\mathrm{PCA}, \mathrm{pH}, \mathrm{O}_{2}$, algal biomass and $\mathrm{BOD}$ were discriminated on the first axis, in opposition to $\mathrm{SiO}_{2}$, conductivity, $\mathrm{NO}_{3}, \mathrm{PO}_{4}$ and flow (fig. 11A). The relative contributions are respectively $41 \%, 37 \%, 65 \%, 60 \%$ then $54 \%$, $24 \%, 32 \%, 63 \%$ and $60 \%$. Three significant factors were extracted on the second axis: $\mathrm{NH}_{4}$ being in opposition to $S M$ and oxydability, with the following relative contributions $39 \%$ then $49 \%$ and $58 \%$. Opposite to upstream sites, there was a change in the position of conductivity which was linked to nutrients and $\mathrm{SiO}_{2}$ and could be a consequence of the tributaries' input.

In the between-months analysis, summer data (5 to 7 ) with biomass as an extracted factor were opposed to spring and autumn data (1 to 4 and 8) with $\mathrm{NO}_{3}$ as an extracted factor. Temperature was discriminated on the second axis (fig. 12A \& B), showing a clear seasonality.

The between-years analysis showed the importance of conductivity, $\mathrm{PO}_{4}$, flow (and $\mathrm{SM}$ ) on the first axis (fig. 12C). The situation of the different sampling sets, which illustrated the differences between years, was visualised fig. 12D. We again found type 1 (1982-1983), while the following years (1984-1985-1986) represented the reference years (type 3).

We proceeded to the graphic representation of the PCA, to reconstitute each of the discriminated factors among the 13 sets of data. The values which are rebuilt by the first axis are $\mathrm{O}_{2}, \mathrm{BOD}, \mathrm{PO}_{4}$ and algal biomass, in relation with flow. The values which are rebuilt by axis 1 and 2 together accounted for $50 \%$ of variance and flow, temperature, $\mathrm{pH}$, oxydability, $\mathrm{SiO}_{2}, \mathrm{NH}_{4}$ and $\mathrm{SM}$ variations are well integrated by this rank 2 model (fig. 13). These results illustrate the importance of organic compound in the SM.

The examination of the eigen values (fig. $4 \mathrm{C}$ ) showed the betweenyears and the between-months variability. As for the preceding sites, factor 2 indicated a well marked intermonths variability.

\section{DISCUSSION}

One of the most important characteristics of rivers is the temporal variability of flow which depends on the spatial position of the stream within the drainage network. In the middle Loire, flow was the most influential factor on the changes in algal biomass, significant negative correlations between flow, $\mathrm{pH}, \mathrm{BOD}$ and algal biomass and positive correlations between flow, $\mathrm{SiO}_{2}, \mathrm{NO}_{3}$ and $\mathrm{PO}_{4}$ were constant at all sites. The "between-months" analysis illustrated the displacements of the pattern of the time course of the seasons from upstream to downstream, with the following shifts in the sampling dates: July 1 to August 2 (Dampierre-enBurly), July 2 to September (SaintLaurent des Eaux) and August 1 to September (Chinon). These results indicated the later algal growth at the downstream site and the earlier 

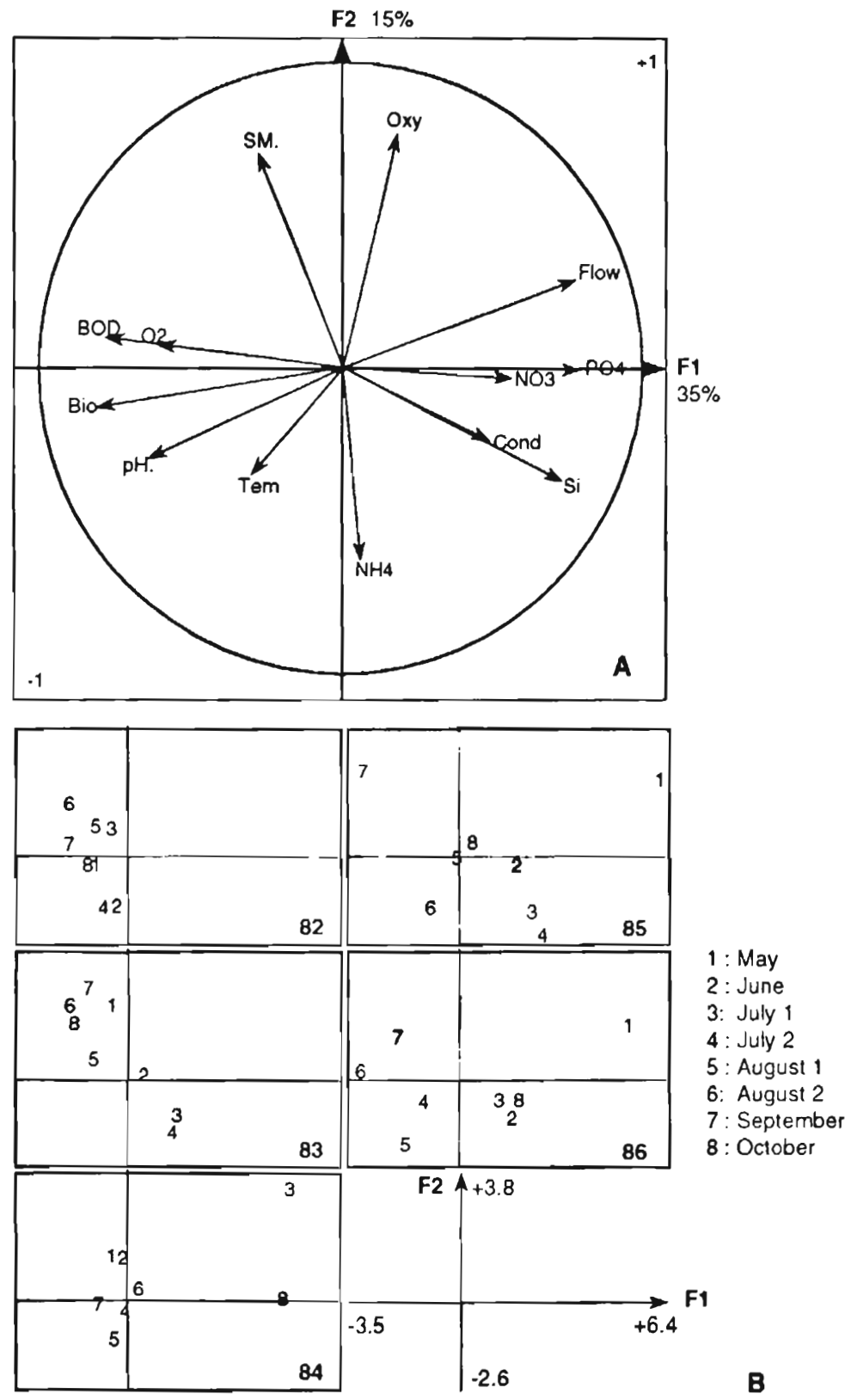

Fig. 11. - Chinon (1982-1986 data). Situation of the measured variables in the plane of axis I and II resulting from PCA. (legends are as in fig. 5).

Fig. 11. - Site de Chinon (données de 1982 à 1986). Représentation graphique des variables mesurées sur le plan formé par les axes I et II de l'ACP (voir légende détaillée fig. 5). 


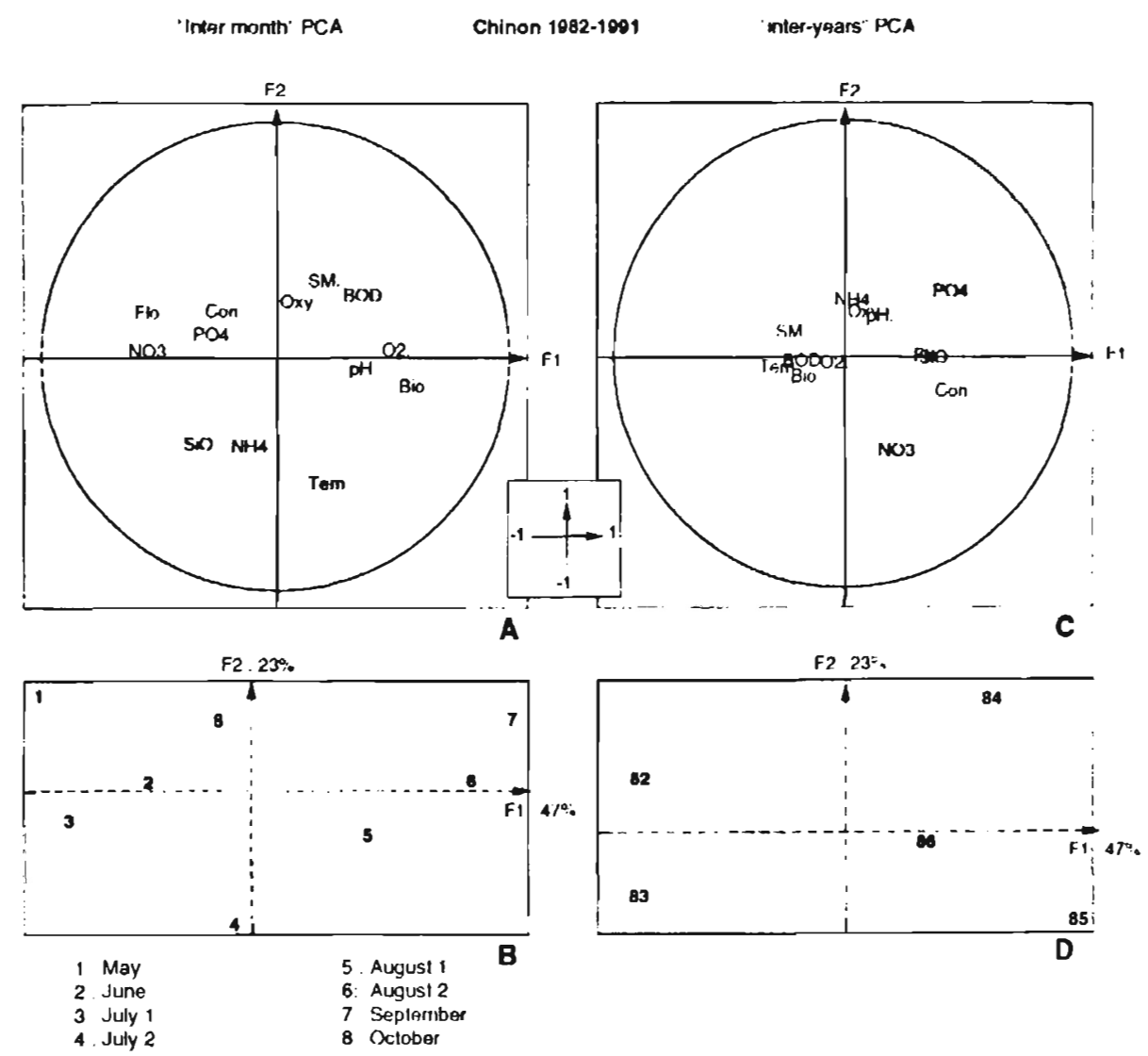

Fig. 12. - Chinon (1982-1986 data). Situation of the measured variables in the plane of axis I and II resulting from between-months and between-years analysis (legends are as in fig. 5).

Fig. 12. - Site de Chinon (données de 1982 à 1986). Analyse inter-mensuelle et interannuelle. Représentation graphique des variables mesurées sur le plan formé par les axes I et II de I'ACP. (voir légende dètaillée fig. 5).

decrease of the algal growth at the upstream site. The warming of the water by a few degrees did not seem to be the principal factor explaining this displacement, which would be due to the changes in population dynamics.

Nutrients, whose quantities have been measured since the seventies (Oudin, 1990), were never depleted in these sites on the Loire, as in other temperate (Lack, 1971; Jones \& Barrington, 1985; Descy et al., 1987) or tropical rivers (del Giorgio et al., 1991). This pattern might be general in the course of the middle and lower part of rivers, by reason of the different kinds of nutrient inputs which occured from the headwaters and tributaries, of rainfall associated with 
agricultural runoff, urban or industrial wastewaters and sewage effluents, and of the unceasing mixing of water and sediments, rapid flushing tending to reduce nutrient sedimentation and thus increase nutrient concentrations in the water (Vollenweider, 1976).

The characteristics of the middle Loire are typical of an eutrophic river, as was confirmed by the measurements of the chlorophyll a content which reached $210 \mathrm{mg} \cdot \mathrm{m}^{-3}$ in summer at Saint-Laurent des Eaux (Khalanski, 1976; Lair \& Sargos, 1981). Oudin (1990) noticed values of $250 \mathrm{mg} \cdot \mathrm{m}^{-3}$ and pointed out that the chlorophyll a content increased strongly from upstream to downstream. Algal biomass (expressed as cell numbers converted to biovolumes) showed strong seasonal variations, with low values in spring (the winter period was not studied) and high values in summer or autumn, associated with high $\mathrm{pH}$ values (close to 10) and high oxygen values (overtaking $20 \mathrm{mg}^{-1}{ }^{-1}$ at some periods). We observed an increase of the algal biomass from Dampierre-enBurly to Saint-Laurent-des-Eaux, it was linked to the decrease in nutrients and silicate, the greatest densities of algae being found at the lower flows.

The situation at Chinon was more complex. From the comparison based on the data obtained from 1982 to 1986 at the three sites (table IV), in this part of the River the $\mathrm{NO}_{3}$ content was higher than at the upstream sites, possibly due to the influence of towns (Tours, Blois) and tributaries (Cher, Indre). Nevertheless, the algal biomass was globally lower and
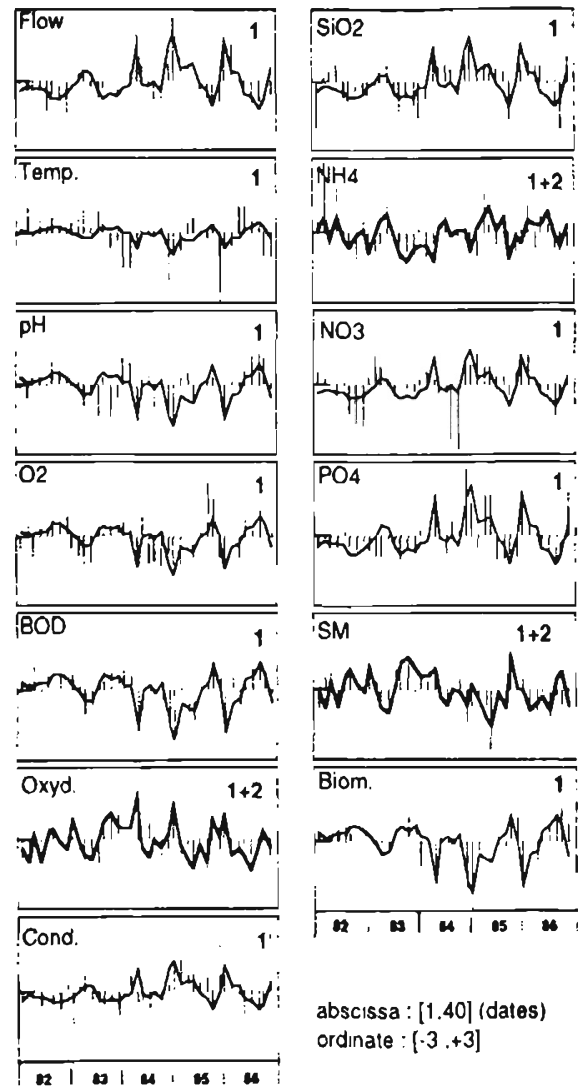

abscissa : [1.40] (dates) ordinate : $[-3 .+3]$

Fig. 13. - Chinon (1982-1986 data). Modelling data after PCA. Chronologically normalized sampled data (bars) and the best model defined by the first axis of PCA (thick lines) and by the first + second axis of PCA (bold lines)

Fig. 13. - Site de Chinon (données de 1982 à 1986). Les barres correspondent aux données normalisées en ordre chronologique et les courbes correspondent au meilleur modèle obtenu sur l'axe 1 (ligne fine) ou sur les axes 1+2 (ligne épaisse).

decreased from Chinon, which confirmed our precedent results obtained from 1977 to 1980 (Lair \& Sargos, 1981). This corresponded to the chlorophyll a data obtained from 1987 to 1989 (Oudin, 1990) which 
decreased at $800 \mathrm{~km}$ from the source at the level where the Indre flowed into the Loire and after the confluence of the Cher also (fig. 14). The higher quantities of silicate would be due to changes in the succession of species (in relation to the increase of the $\mathrm{NO}_{3} / \mathrm{PO}_{4}$ ratio), as well as a decrease of primary production. An increase in flow gives a greater load of suspended material, so the available light in the water column is less favourable to algae and might control primary production. Moreover, at Chinon, meanflow increased due to the large tributaries which enter upstream of Chinon and, although nutrient levels were highest at this station, they were consistent with lower biomass. We noticed that, despite a higher flow, the phytoplankton biomass did not seem to be compensated by the

Table IV. - Variable characteristics of the River on the basis of data collected from 1982 to 1986 at $D=$ Dampierre-en-Burly, $S=$ Saint-Laurent-des-Eaux, $C=$ Chinon.

Tableau IV. - Données recueillies de 1982 à 1986 aux différents sites et identiques pour chacun des sites suivants: $D=$ Dampierre-en-Burly, $S=$ Saint-Laurent-des-Eaux, C = Chinon.

\begin{tabular}{|c|c|c|c|}
\hline $\begin{array}{c}\text { variables } \\
\text { (1982 to 1986) }\end{array}$ & $\begin{array}{l}\text { minimum } \\
\text { maximum } \\
\text { mean } \\
\text { (D) }\end{array}$ & $\begin{array}{l}\text { minimum } \\
\text { maximum } \\
\text { mean } \\
\text { (S) }\end{array}$ & $\begin{array}{l}\text { minimum } \\
\text { maximum } \\
\text { mean } \\
\text { (C) }\end{array}$ \\
\hline \multirow[t]{2}{*}{ flow $\left(m^{3} \sec { }^{1}\right)$} & $\begin{array}{c}64 \\
771\end{array}$ & $\begin{array}{c}73 \\
864\end{array}$ & $\begin{array}{c}90 \\
1580\end{array}$ \\
\hline & 184 & 203 & 307 \\
\hline \multirow[t]{3}{*}{ temperature $\left({ }^{\circ} \mathrm{C}\right)$} & 9.9 & 12.6 & 10.8 \\
\hline & 24.2 & 28.3 & 26.2 \\
\hline & 19.3 & 19.2 & 20.1 \\
\hline \multirow{3}{*}{$\mathrm{SiO}_{2}$ (mg. (mg. ${ }^{1}$ ) } & 1.7 & 0.5 & 1.4 \\
\hline & 10.9 & 11.9 & 13.0 \\
\hline & 5.8 & 5.5 & 6.2 \\
\hline \multirow[t]{3}{*}{$\mathrm{NO}_{3}\left(\mathrm{mg} \cdot \Gamma^{1}\right)$} & 0.5 & 0.5 & 0.5 \\
\hline & 11.4 & 11.3 & 16.4 \\
\hline & 3.4 & 3.5 & 7.7 \\
\hline \multirow[t]{3}{*}{$\mathrm{PO}_{4}\left(\mathrm{mg} \cdot{ }^{-1}\right)$} & 0.02 & 0.02 & 0.02 \\
\hline & 0.47 & 0.39 & 0.38 \\
\hline & 0.18 & 0.12 & 0.13 \\
\hline \multirow[t]{3}{*}{$\mathrm{NO}_{3} / \mathrm{PO}_{4}$} & 2.5 & 2.5 & 2.5 \\
\hline & 24.25 & 29.17 & 59.23 \\
\hline & 18.89 & 28.97 & 43.15 \\
\hline \multirow[t]{3}{*}{$\mathrm{NH}_{4}$ (mg.l $\left.{ }^{1}\right)$} & 0.01 & 0.01 & 0.01 \\
\hline & 0.60 & 0.87 & 0.84 \\
\hline & 0.07 & 0.41 & 0.28 \\
\hline \multirow[t]{3}{*}{$S M\left(m g \cdot r^{1}\right)$} & 6.4 & 11.2 & 18.0 \\
\hline & 47.6 & 50.8 & 78.8 \\
\hline & 25.6 & 32.8 & 41.6 \\
\hline \multirow[t]{3}{*}{ oxydability $\left(\mathrm{mg} \cdot \Gamma^{-1}\right.$ ) } & 1.7 & 2.1 & 2.1 \\
\hline & 5.4 & 4.7 & 6.4 \\
\hline & 3.1 & 3.3 & 3.6 \\
\hline algal biomass $\left(\mathrm{mg} \cdot \mathrm{m}^{-3}\right.$ ) & 1.0 & 1.1 & 0.3 \\
\hline \multirow{2}{*}{ (cell biovolumes) } & 4.0 & 58.3 & 45.4 \\
\hline & 16.0 & 20.9 & 17.3 \\
\hline
\end{tabular}




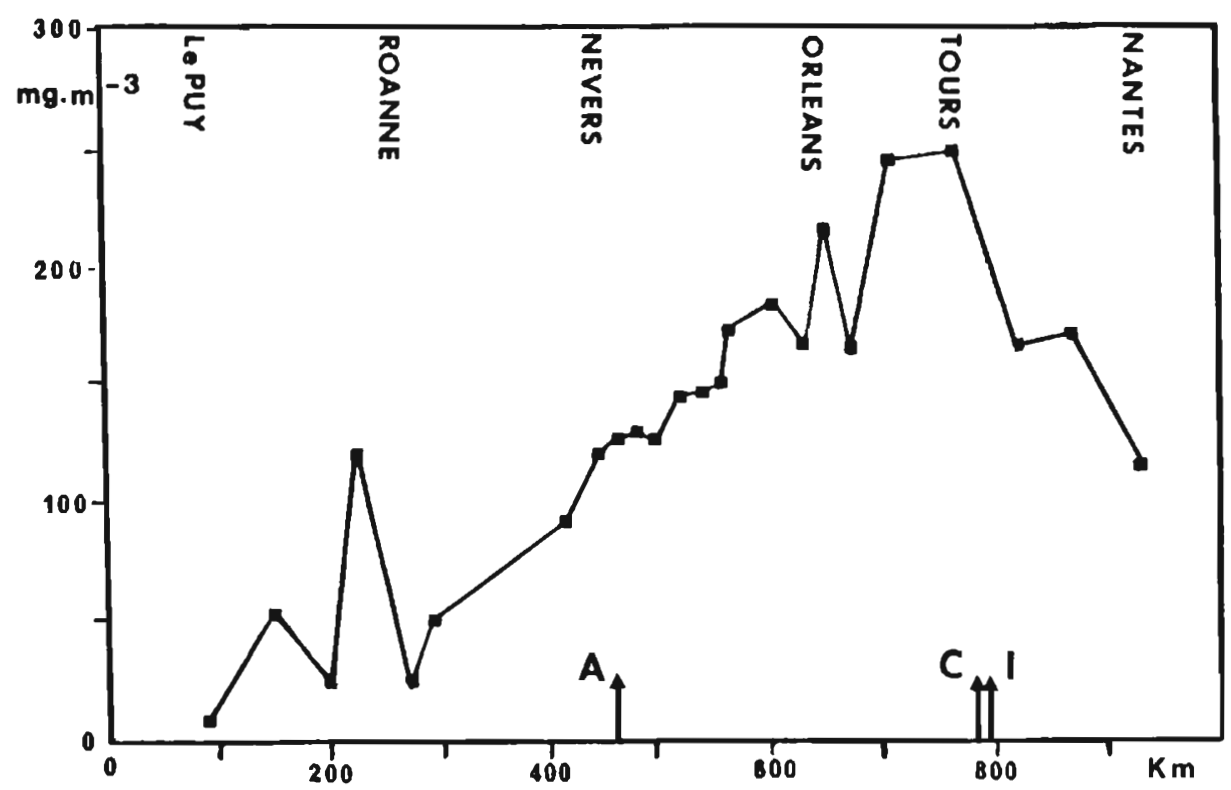

Fig. 14. - Variations of chlorophyll a concentrations (1987 data) in the course of the Loire (modified from Oudin, 1990). Arrows indicate confluence of tributaries that flow into the Loire $(A=A l l i e r, C=$ Cher and $I=$ Indre).

Fig. 14. - Variations des teneurs en chlorophylle a (données de 1987, d'après Oudin, 1990) sur le cours de la Loire. Les flèches indiquent la confluence des affluents $(A=A$ llier, $C=C h e r, I=$ Indre) avec le fleuve.

derived periphyton biomass, which is opposite to the observations of Lack (1971) in the River Kennet. In addition, temperature was lower than at Saint-Laurent des Eaux.

In the course of previous studies, we have observed that the maximum density of Rotifers was between 2.4 to 4.7 times higher at Chinon than at Saint-Laurent des Eaux. In 1978 from the upstream to the downstream station we have measured the following maximum densities: $45.800-60.500$ - 155.900 and 372.300 ind. $I^{-1}$ (Lair \& Sargos, 1981). The grazing activity of these planktonic organisms can be intense in lakes (Lair \& Oulad Ali, 1989), therefore we suggested that their grazing pressure might be also one of the reasons for the decrease of the algal biomass at this downstream station.

The diluting effect of floods which can be seen in the negative correlation between flow and conductivity was observed at Dampierre-en-Burly and Saint-Laurent-des-Eaux only. Besides hydrology, in the absence of nutrient limitation, the factors controlling algal biomass appeared to be flow and temperature, supplemented by water quality (discharge of anthropogenic substances, such as $\mathrm{NH}_{4}$, above Chinon). The suspended mate- 
rial was linked to high flow periods as well as the growing season of the algae and acted as an independant factor. In this long term study we observed that inter-month changes (in connection with unpredictable floods) were slightly higher at Dampierre-enBurly and Chinon than the inter-annual changes, and inversely for SaintLaurent-des-Eaux, but over all the inter-month variability seemed to be higher than the inter-annual variability.

The end of this long term study was characterized by some of the driest years and we have observed in 1991 an increase in the development of Cyanobacteria. Without prejudice of the natural heterogeneity of the River, these results will conduce to observe with more attention the seasonal succession of the different groups and species in relation with the characteristics of the stations, with the proportion between $\mathrm{SiO}_{2}$ (which was the most significant variable at the level of Chinon). In agreement with del Giorgio et al., (1991), even if taxonomical changes had not occured, we will assess changes in the mode of distribution of species and the proportions between groups modifying the phytoplankton community dynamics. This aspect will be developed in a next work about the development of the planctonic and fixed algae.

\section{REFERENCES}

Bianchi M., Marty D., Bertrand J.-C., Caumette P. \& Gauthier M., 1989. Microorganismes dans les écosystemes océaniques. Masson $447 \mathrm{pp}$.
Carrel G., Barthélémy D., Auda Y. \& Chessel D., 1986. Approche graphique de l'analyse en composantes principales normée: utilisation en hydrobiologie. Acta CEcologica generalis, 7, 189-203.

Chessel D. \& Dolédec S., 1992. ADE Software. Multivariable Analyses and Graphical Display for Environment Data. Version 3.3 User's manual. Ecologie des Eaux Douces et des Grands Fleuves. URA CNRS 1451. Université Claude Bernard Lyon I, 69622 Villeurbanne Cedex.

Descy J.-P., Servais P., Smitz J.S., Billen G. \& Everbeca E., 1987. Phytoplankton biomass and production in the River Meuse (Belgium), Wat. Res. 21: 1557-1566.

Dolédec S. \& Chessel D., 1987. Rythmes saisonniers et composantes stationnelles en milieu aquatique. I - Description d'un plan d'observation complet par projection de variables. Acta CEcologica Generalis, 8, 3, 403-426.

Dolédec S. \& Chessel D., 1989. Rythmes saisonniers et composantes stationnelles en milieu aquatique. II - Prise en compte et élimination d'effets dans un tableau faunistique. Acta OEcologica Generalis, 10, 3, 207-232.

del Giorgio P., Vinocur A.L., Lombardo R.J. \& Tell H., 1991. Progressive changes in the structure and dynamics of the phytoplankton community along a pollution gradient in a lowland River - a multivariate approach. Hydrobiologia, 224, 129-154.

Jones R.I. \& Barrington R.J., 1985. A study of the suspended algae in the River Derwent, Derbyshire, U.K. Hydrobiologia, 128, 225-264.

Khalanski M, 1976. Mesure de pigments planctoniques en Loire moyenne, au voisinage des centrales nucléaires de St Laurant, Chinon et du site de Dampierre-en-Burly. Rapport E.31-76/No 15 (Diff. EDF).

Khalanski M., 1987. Impact hydrobiologique du centre de production nucléaire 
de Dampierre-en-Burly. Bilan. Rapport HE/32-87.17 (Diff. EDF).

Lack (T.J.), 1971. Quantitative studies on the phytoplankton of the rivers Thames and Kennet at Reading. Freshwat. Biol. 1: 213-224.

Lair N., Millerioux E. \& Restituito F., 1978. Examen physicochimique et répartition du plancton de la Loire en période d'étiage (été 1976) au niveau de la centrale nucléaire de St-Laurent-desEaux. Cahiers d'Hydrobiologie de Montereau, 6, 53-80.

Lair N., 1980. The Rotifer fauna of the River Loire (France) at the level of the nuclear power plants. (Second intern. Rotifers Symposium, Gent, Belgium) Hydrobiologia, 73, 153-160.

Lair N., Pihan J.C. \& Nourrisson M., 1980. Conception et principaux résultats des études hydrobiologiques effectuées sur différents sites électronucléaires. Rev. Gén. Nucléaire. 1, 31-44.

Lair N. \& Sargos D., 1981. Dynamique des populations planctoniques en Loire moyenne. Ann. Stat. Biol. Besse-enChandesse, 15, 60-114.

Lair N. \& Oulad Ali H., 1990. Grazing and Assimilation rates of natural populations of planktonic Rotifers Keratella cochlearis, Keratella quadrata and $\mathrm{Kel}$. licottia longispina living in an eutrophic lake. Hydrobiologia, 194, 119-131.

Oudin L.C., 1990. Modélisation de l'eutrophisation en Loire. Modèle POLUPA. La Houille Blanche 3/4, 195-206.

Sorensen J., 1987. Nitrate reduction in marine sediments: pathways and interaction with Iron and Sulfur cycling. Geomicrobiol. J. 5: 401-421.

Thioulouse J. \& Chessel D., 1987. Les analyses multitableaux en écologie factorielle. I. - De la typologie d'état à la typologie de fonctionnement par l'analyse triadique. Acta OEcologica Generalis, 8, 463-480.

Vollenweider R.A., 1976. Advances in defining critical loading levels for phosphorous in lake eutrophication. Mem. Ist. ital. Idrobiol. 33: 53-83. 